\title{
Managing Human Capital as a Strategic Source of Sustainable Enterprise Development and Competitive Advantage
}

\author{
Abdul Amid Aziz Jalloh, Feng Ming
}

\begin{abstract}
Managing institutions workforce encompasses enormous challenges, which warrants careful assessment of elements that constitute its effective and efficient management to ensure outstanding performance, organisational development and sustainability is enhanced. This study examined procedures and processes of managing human capital as a strategic source of sustainable enterprise development and competitive advantage. In this regard, it reviewed several pieces of literature that identified considerable elements of human capital management. This study however employed descriptive quantitative and correlational methodsfor the collection, classification and presentation of data, which was obtained through the distribution of three hundred (300) questionnaires to employees of 2 financial institutions. Data obtained from survey was analysed using percentages and Pearson correlation. Results of data analysed showed that staff capacity building (training and development), employee engagement and commitment and compensation and rewards management serves as strategic elements which facilitate the efficient management of organisations human capital. Further facts revealed, emphasised that, the judicious management of aforementioned components reinforces organisations capacity to strategically position their workforce for competitive excellence. More findings disclosed that, an efficient performance management system ensures the conduct of staff capacity building programmes and the provision of adequate toolsfacilitate the enhancement of skills and competencies for effective job performance. Also, recognising employees for their immense contributions through financial and non-financial rewards strengthens organisations management capability. In addition, effective engagement strengthens employer-employee relationship which supports and improve task, adaptive and contextual performance. In relation to the foregoing facts about human capital management, this study is noteworthy to human capital specialists, general management practitioners, business consultants and training and development specialists.
\end{abstract}

Key words: Human Capital, Strategic Source, Sustainable Enterprise Development, Competitive Advantage.

\section{NTRODUCTION}

Numerous schools of thought and management practitioners have emphasised the critical process of managing organisations most precious resource and such expression is acknowledged by many researchers and business consultants.

Revised Manuscript Received on September 13, 2020.

*Corresponding Author

Abdul Amid Aziz Jalloh,* PhD Scholar: School of Economics and Business Administration, Chongqing University- China. Email: azizhrmjay@gmail.com

Professor Feng Ming, School of Economics and Business Administration, Chongqing University- China. Email: fengming@cqu.edu.cn

(c) The Authors. Published by Blue Eyes Intelligence Engineering and Sciences Publication (BEIESP). This is an open access article under the CC BY-NC-ND license (http://creativecommons.org/licenses/by-nc-nd/4.0/)
Financial institutions specifically banks in Sierra Leone have exhibited quantum of challenges encompassing the management of their human capital and how such resource could be effectively and efficiently managed to produce results necessary to position their organisations at strategic level in the competitive landscape.

The aforementioned is substantiated through the conduct of an assessment on employee management for outstanding performance and organisational development conducted by some scholars within the country. Jing et al 2019, Kolade 2019, Godfred and Pattanayak 2019,Aino et al 2018 \&Luminita et al 2016 conducted similar investigations regarding intellectual capital form a wide spectrum of organisational performance, dealing with the general elements that constitute IC. However, considering the constituents of intellectual capital which are human, social and structural capital, this study determines to examine the process of managing human capital as a strategic source of enterprise sustainable growth and competitive excellence. This study however shift a bit from previous works to focus on the most precious resource amongst resources utilised in organisations.Humancapital in its entirety encompasses quantum of attributes that are occasionally exhibited and such demonstrated characteristics makes it more difficult for human capital management specialists to diagnose and discover different motivating elements that could be used to address unpleasant situations, as employees desires on effective job performance rest with their satisfactory situations. This makes organisations in today's competitive landscape to constantly assess their motivating tools and competitive strategies, engage in worthwhile adventures and position themselves strategically for growth and sustainability.In this regard, numerous businesses and management practitioners therefore concentrate on handling human capital issues to ensure competitive advantage is achieved. However, general management practitioners consider HCM as a critical sensation whose components are difficult to unravel. Corporate consultants have defined the concept, but other specialists are yet to understand the dictates of its theory. In this regard, very few could value the nature of its existence which is why enterprises operations have been experiencing difficulties in implementing the concept (Adler and Kwon 2002, Berger et al 2014, Berger and Udell 2002,Alavi and Leidner 2001, Bitler et al 2001, Stewart 1997, Sveiby 1997,Anand et al 2007 \& Boot 2000).

Researchers and large-scale business leaders consider the application of human capital to be a great challenge.

Published By:

Blue Eyes Intelligence Engineering DOI:10.35940/ijmh.A1124.095120

Journal Website: www.ijmh.org

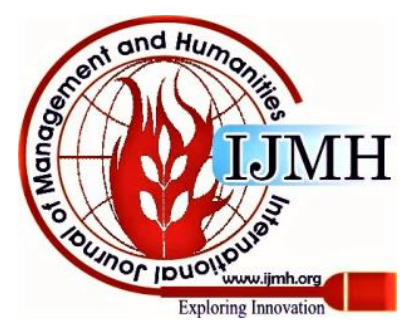


Regardless of the several challenges surrounding the concept, modernenterprises must contend with their counterparts in multidimensional and challenging circumstanceswhich note from universal, the growth of technology and progressive transmission of innovative technology, to the expansion and utilisation of knowledge(Hitt et al 1998, Butler and Goktan 2013 \& Critchfield et al 2004,).

Even though human capital is measured as one of the most critical components of business development, organisations still desire its strategic values for creative performance(Sharabati et al 2010 \& Ghoshal 2005).The realism of knowledgeable resources has disclosed the significance of knowledge management, which is a fundamental principle of economic progress. The effect of monetary possessions is condensed in valuation to the effect of imperceptible possessions. This indescribable intangible could not be appraised in the financial terms that organisations are presently familiarised with(Andreeva and Kianto 2012, Beugelsdijk 2008 \& David et al 2008). Organisations and business leaders cannot question the impact of its strategic operations; it starts from capture, codification, and dissemination of information, through the acquisition of new competencies via training and development(Bontis et al 2000 \& Haggerty et al 2001).

The greatest challenges researchers and academics face today is how to structure the phenomenon of intellectual capital with appropriate theoriesto cultivate additional and demanding concept of this indefinable intangible. Intangible resources are reputation, product fairness, and the foremost significance of the aforementioned is human capital(Sydler et al 2014, Mayer and Argyres 2004\&Bowen and Ostroff 2004). Management schools of thoughts and researchers have presented arguments and evidential facts which state that; supremacy in competitive environment is enhanced by intangible resources, and their scarcity makes it tough for rival companies to imitate. Therefore, organisations must consider new methods of gaining lasting benefit and engage in new forms of competition(Breaugh and Starke 2000, Nickerson and Silverman 2003, Nonaka and Takeuchi 1995 \& O'Brien 2003). One popular approach to understanding competitive dynamics is the resource capacity of an enterprise; which human capital serve asprincipal contributing factor towards outstanding performance. To understand why certain competitive strategies are more effective than others, one must consider the distribution of resources in competing firms. Although a particular organisation may retain more or less of a specific resource, sustainable benefit is attained when a certain organisation's resources are rare, treasured, and difficult to emulate by rival institutions(Cabello-Medina et al 2011, Petersen and Rajan 2002,Cabritaand Bontis 2008, Romano et al 2001,Bontis 1998, Saparito et al 2013 \& Sasson 2008). Competitive advantages that are sustainable, ultimately lead to superior performance. Organisations should consider the significance of tangible possessions such as structures, equipment, or accessibility to capital. Tangible resources plays a pivotal role and areconsidered to be more viable and potential causes for competing benefits in traditional competitive landscape (Chang et al 2016,Nonaka and Takeuchi 1995, Sasson and Fjeldstad 2009\&Adler and Kwon 2002). Accessibility of incorporated resources and the challenges face to imitate them, gives an organisation edge

over competitive practices. Business institutions desiring to pursue competitive gain through workforce must ensure that they recruit and retain the right personnel, with the necessary skills and competencies, and provide the required motivating tools to enhance high-level performance (Alavi and Leidner 2001,Anand et al 2007,Jackson et al 2003, Simerlyn and Li 2000\&Andreeva and Kianto 2012).

Management researchers have established that, among the constituents of intellectual capital, human capital is acknowledged as the most significant; nevertheless critical for competitive advantage since imitating such precious resource could be a challenge for rival institutions. Researchers mostly concentrate on business operations when they examine pieces of literature to describe the role human capital plays towards justifiable growth; such practice is routed to measure the effects viable advantage 2008, Stein 2002,Stewart 2001, Tetlock 2000,\& Uzzi and Gillespie 2002). Organisations operations have therefore been designed by the philosophy of IC which recognise human, relational and organisational capital as the foremost magnitudes of intellectual capital.Conceptualising intellectual capital requires an expansion which includes social and environmental resources that unravels the ve contribution of these assets to organisationa development (Barney 1991,Bontis et al 2000, Uzzi and Lancaster 2003 \& Vincente-Lorente 2001).Knowledge management practitioners contribute towards the development of organisations, particularly with a drive to manage human capital effectively. These practitioners have been entrusted with enviable assignment to channel their organisations intelligence resource as a strategic source of knowledge management specialist, who ensures that new competencies and abilities developed by the workforce are in consonance with duties assigned (Breaugh and Starke 2000 \& Wooldridge 2003).

\section{LITERAUTE REVIEW}

A. Intellectual Capital and Human Capital Theory

Intellectual capital (IC) is described as the knowledge, information; intellectual property and understanding that is utilised to establish affluence. Measuring intangible assets is and individual variables included in the analysis. Simple financial procedures haven't been able to ascertain the understanding of the multifaceted nature of these asset which includes organisational or structural capital, social capital and human capital (Schultz1961, Wintoki et al 2012,Cabello-Medina et al 2011Cabrita and Bontis 2008,Prusak 1998 \& Berger et al 2014).Amongst IC's skills and knowledge, required by organisations to achieve maximum benefits. The capability of human reasoning is either natural or developed and components of such precious resource are qualities that are treasured and improved by suitable ventures.

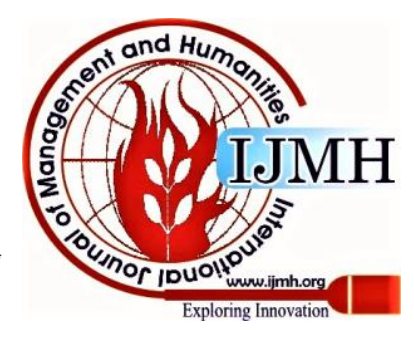


Organisations are given distinct character through outstanding employees, who possess the necessary skills, abilities and competencies required to accelerate organisations growth (Chang et al 2016, Berger and Udell 2002,Evans et al. 2015Adler and Kwon 2002 \& Bitler et al 2001).

Among the resources (financial, material, human and information) utilise by enterprises, the human component has the capability of acquiring knowledge, introducing changing philosophies and concepts, innovate, instils creativity and if satisfactory motivated propels the success and sustainability of organisations (Prusak 1998\&Alavi and Leidner 2001). The added value people contribute to an organization is emphasized by human capital theory which esteems employees as resources and that, developing their capacity will create valuable dividend for organisations (Jameton and McGuire 2002,Anand et al 2007 \& Boot 2000). The philosophy of manpower as a source is associated with the resource capacity possessed by advantage necessitates organisations to develop a team of competent personnel, whose skills and competencies cannot be imitated or probably replaced by other competitors in the business environment (Nonaka and Takeuchi 1995, Butler and Goktan 2013\&Saparito et al 2013). The advantages of employing human capital emphasised that, human capital possesses the required knowledge and capabilities that is not simply copied by competitors. Human process advantage emphasise the critical aspect of imitating possessed competencies and such values can only revolve within an organisation which facilitates knowledge transfer through interdepartmental collaboration and management development (Andreeva and Kianto 2012,Beugelsdijk 2008, Uzzi \& Lancaster 2003).

B. Social Capital, Social Creativity, and Organizational /Structural Capital

Social capital is one of the machineries of intellectual capital that comprises knowledge obtained from systems of interactions within and outside business institutions. Social wealth is the structures of social life, systems, standards and belief that empower contributors to successfully achieve common objectives. The reality of social creativity brought about the exploration of innovative methods of knowledge conception, externalisation, incorporation and dissemination. Externalising employee(s) implicit knowledge is a supportive mechanism for enhancing social creativity (Anand et al 2007, Boot 2000Adler and Kwon 2002 \&Berger et al 2014). Individual implicit knowledge serves as an instinctive decision and common intelligence that fixes up an issue without essentially elucidates its content. Group tacit knowledge is described as the distinctive knowledge that exists in the practices of interactions which is develop through harmonious working relationships as organisations progresses (Alavi and Leidner 2001,Sveiby 1997\&Berger and Udell 2002). Organisation's information stored in databanks and booklets is its institutionalised knowledge possessed, which is referred to as organisational capital. The controversial phenomenon about the choice of the concepts between structural and organisational capital is clarified by many schools of thought, who emphatically stated that, considering the quantum of knowledge that resides and own by organisations, it has been justified that the concept should be termed organisational capital rather than structural organisations, which recommends that, attaining reasonable

capital (Bitler et al 2001, Stewart 1997Critchfield et al 2004\&Hitt et al 1998).

\section{Competitive Strategy and Knowledge Management}

In a competitive environment, every institution competing with rivals has a competitive strategy, whether explicit or implicit. The development of this approach is evidently done through proper scheduling of procedures established through numerous divisions of an enterprise. A competitive strategy is developed as a comprehensive method on how enterprises compete with rival institutions, employ different strategies and formulate guiding principles required to achieve strategic objectives (Butler and Goktan 2013,Ghoshal 2005\&Sharabati et al 2010). Knowledge management is any procedure or exercise of generating, gaining, capturing, distributing and utilising knowledge to enhance outstanding performance. Implicit competence is an individual possession stowed in theminds of employees which is accrued through learning andexperience. The development of such knowledge happens when collaborating with other people through effective interactions (David et al 2008,Andreeva and Kianto 2012\&Beugelsdijk 2008). The growth of tacit knowledge occurs through exercise of experimental process and understanding of achievement. It is therefore context-specific which is critical to form, document, or express as it comprises personal perceptions, instincts and speculations (Sydler et al 2014\&Bontis et al 2000). The instinctual and individualised aspect of tacit knowledge makes it critical to be expressed and transferred to others. The extent to which it can be shared, depends on the capability and readiness of the individual who possess it and decides to transfer it to others (Mayer and Argyres 2004\&Bowen and Ostroff 2004). Explicit knowledge is codified and can be stored in databanks, websites, documents, emails etc. Such knowledge is made available to people through the distribution of organised information in systematic procedures and prescribed languages (Haggerty et al 2001). Organisations cannot totally separate explicit knowledge from tacit knowledge since both complement each other and one without the other makes it difficult to understand the dictates of both concepts. In this regard, kin consideration should be expressed on both components as they collectively contribute towards human capital intelligence retain for competitive advantage (Nickerson and Silverman 2003, O'Brien 2003\&Breaugh and Starke 2000).

\section{Learning and Development and Performance Management}

Learning enables the acquisition and development of new knowledge, skills, capabilities, behaviours and attitudes. Learning is an unceasing progression and an endless journey which does not only improve current competencies but also facilitate the growth and improvement of employees attributes, which empower them for outstanding levels of task performance (Nonaka and Takeuchi 1995,Petersen and Rajan 2002\&Sasson and Fjeldstad 2009). Development ensures employees competencies and abilities are enhanced and realised through the delivery of learning involvements that is directed and managed by individual employees (Adler and Kwon 2002\&Cabello-Medina et al 2011).

Published By: 
Learning empowers employees to improve their current techniques and levels of understanding certain basic principles which help them progress to the required highlevel skills, knowledge and competencies for addressing performance challenges (Romano et al 2001\&Nonaka and Takeuchi 1995,).

Performance management as a strategic component of organisational development requires systematic process of cultivating outstanding enhancement through the transformation of individual and teams performance. Organisations can better understand how to manage performance through the development of an approved structure of planned objectives, principles and capabilities that match up with its operations (Cabrita and Bontis 2008,Chang et al 2016Saparito et al 2013). One of organisations challenge is managing workforce performance which involves acquiring and utilising knowledge required for sustained competitive advantage. Organisations should focus on future performance arrangement; enhance individual growth instead of emphasising on retroactive performance appraisal (Sasson 2008\&Bontis 1998). Appraising performance is significant in organisational development as it produces feedback of activities implemented, creates an impact, provide the basis for building further achievement and examine unsuccessful ventures, which give rise to institute corrective measures and address fissures (Anand et al 2007\&Jackson et al 2003).

\section{E. Reward Management and Competitive Advantage}

The prescriptions of reward management encompasses approaches, guiding principles and procedures essential to guarantee that, employees contribution towards enterprises growth is acknowledge by monetary and material benefits.Reward management is the design, implementation and maintenance of reward systems (payment methods and procedures), which aim to meet the requirements of both the organisation and its stakeholders (Stewart 2001,Uzzi and Lancaster 2003,Breaugh and Starke 2000\&Bontis et al 2000 ,). Its general objective is to remunerate employees justly, impartially and consistently in relation to their worth in organisations. Reward management does not only concern about financial compensation and workers benefits. It is similarly concerned with non-financial compensation such as gratitude, knowledge and prospects for employees' growth and increased job responsibility (Uzzi and Gillespie 2002,Beugelsdijk 2008,Peteraf 1993\&Alavi and Leidner 2001).Global competitive business strategies are based on differentiation by unique specialisation in terms of quality of product, service technology or cost leadership. When Peters \& Waterman introduce the world of business to the notion of excellence, the unwavering pursuit of excellence provides the basis for an unmatchable sustainable competitive advantage. However, distinction in performance is and forever will be sustainable competitive advantage (Wooldridge 2003, Simerlyn and Li 2000,Jackson et al 2003\&Stein 2002). High-level involvement of manufacturing managers in strategic planning process to improve business units, leads to the attainment of superior competitive performance. Sustainable competitive advantage is derived from the possessions and competencies of the following qualities: precious, rare, imperfectly imitable and not exchangeable (Andreeva and Kianto 2012,Vincente-Lorente 2001,Tetlock 2000\&Stewart 1995). Industrial competitive priorities such as abilities and choices

or practices on important resolutions and their internal coherence can be the base for attaining justifiable or longlasting benefit over competitors, thus producing superior business performance. SCA as organisations approach,obviously signifies influential corporate strategy today. Enterprises whose competitive strategies and operations are sustainable can outweigh the operations of rival institutions in competitive environment (Barney 1991,Evans et al. 2015,Wintoki et al 2012,Chang et al 2016\&Cabello-Medina et al 2011). Achieving an advantage in the competitive landscape requires the identification of different products approaches, developing and redesigning accumulate intellectual possessions; all of these can be connected to make organisations succeed in extreme competitive marketplace (Cabrita and Bontis 2008\&Adle and Kwon 2002).Worthwhile benefit has developed more operations through the development of internet operatives, which has given more scope to competitive practices, nvironmental, and technological development (Berger et al

\section{F. Competition and Sustainability}

Competition is an encounter amongst enterprises to win customer acceptance and allegiance. It is the inter-market competition amongst industries trying to gain a larger market segment. Four chief pointers related to industries competitive environment are: easy replacement of merchandises, continuous influx of competing goods, prompt obsolescence of products, and speedy modification of manufacture technologies. Employees' personal motivation to compete, constitute a strategy that is found to be the maximum influential and productive component of (Schultz 1961,Bitler et al 2001,Prusak 1998,Anand et al 2007\&Prusak 1998).Challenges of operations are linked to crisis management Managing crisis is a strategic and tactical management principle which can absolutely influence organisation's competitive competence and prospect for lasting existence, and sustainability. Competitive substitutability, industrial scope and entry charges specified by the level of manufacturing concentration (Jameton and McGuire 2002,Alavi and Leidner 2001\&Boot 2000).

\section{METHODS}

\section{A. Research Design}

Good research design minimises bias and maximises the accuracy of the data obtained and should have as few errors as possible. The most important requirement of good research strategy is to provide adequate information so that the research problem could be examined through a wider perspective (Manish et al 2017,Barai and Mohanty 2014\&Saxena 2015). This investigation used descriptive quantitative survey and correlational method which encompasses collection, classification and presentation of data for descriptive analysis, discussion and objective conclusion.

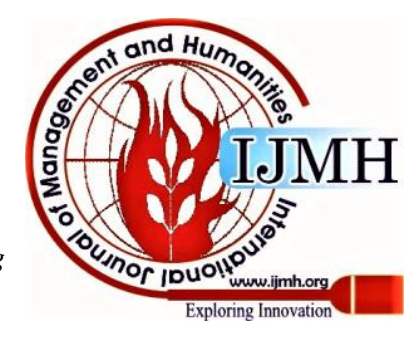


This method was deemed necessary and suitable for investigating the process of managing human capital as a strategic source of worthwhile advantage.

\section{B. Research Area}

This research was conducted in Freetown with specific focus on assessing components required for effective management of institutions human capital in two financial institutions such as Sierra Leone Commercial Bank (SLCB) and Rokel Commercial Bank (Sierra Leone Limited) (RCBSLL).

Contributions of aforementioned institutions are enormous and their operations are strategic in the capital city which prompted the direction of such endeavour to use such institutions as case studies.

\section{Sampling of Respondents}

For some research questions, data collection can be done through an entire population that is of a manageable size. However, researchers should not presume that results obtained from a census survey will provide more satisfactory information than data collected from a sample that represents an entire population (Winerip 2013\&Y1ldiz et al 2014).Probability sampling, which is also referred to as representative sampling is regularly used and commonly associated with survey based research approaches, where inferences are made from samples selected from a population to respond to or provide answers to research questions in order to achieve research objectives (Dineen and Williamson 2012,Edler et al 2012\&Giangreco et al 2012). This approach used probability sampling as it was deemed suitable for such endeavour. When a sampling frame has been chosen and requires a representative sample size to be selected, further steps necessitates the selection of the most suitable sampling technique to obtain a representative sample (Walters 2013\& Lebedev et al2015). Accurate and easily accessible sampling frame which provide a comprehensive list of the entire population stored in a computer, facilitate the best use of a simple random sampling technique (Lee et al 2017\&Gubbi et al 2015). This research used a simple random sampling which facilitated the accurate selection of 300 sample units from the sample frame. The stated sample size accurately represented the population been studied.

\section{Research Instruments}

Considering the nature of this study which is descriptive in its conduct, questionnaire was used for gathering primary information through survey. Questionnaires are instruments completed by respondents themselves. They are often classified as individually managed questionnaires and are the most regularly used technique for data collection in management research (Alavi and Leidner 2001,Adler and Kwon 2002\&Berger and Udell 2002). They are relatively easy to use, inexpensive, and are often the more reasonable substitute for quantifying unobservable paradigms such as attitudes, values and preferences, intentions, and personalities (Berger et al 2014,Anand et al 2007\&Bitler et al 2001). Questionnaire was designed specifically for this study, using the Linkert scale system which includes: 5=Strongly Agree, 4=Agree, 3=Neutral, 2=Disagree, $1=$ Strongly Disagree.It was classified as the most appropriate instrument for collecting primary data suitable for addressing issues of concern in this investigation. This study distributed 400 questionnaires to sample units for responses, however, 300 were retrieved filled with information from respondents, who are classified as 180 male with a percentage of $60 \%$ and 120 female as $40 \%$. The aforementioned shows gender disparity which is because, institutions employed more male than female. Classification of elements used in this research are obtained from previous researches which note the following: competitive strategy and knowledge Management adopted Ghoshal 2005, Butler and Goktan 2013\&Sharabati et al 2010, whilst learning and development and performance Management anchored on Nonaka and Takeuchi 1995,Petersen and Rajan 2002\&Sasson and Fjeldstad 2009. Nevertheless,reward management and competitive advantage was obtained from investigations conducted byBontis et al 2000,Uzzi and Lancaster 2003,Breaugh and Starke 2000\& Stewart 2001.

\section{E. Data Analysis}

Data were gathered from each sample unit/respondent and was tabulated using statistical instrument, which revealed percentages of respondents and proportion of respondents' answers among presented indicators. Data analysed revealed respondents level of perception about considerable elements in the effective management of organisations human capital. Correlation was used to assess the strength of each variable tested and further relate such variable to others and measure the strength of the relationships amongst performance, training, engagement and rewards. This was used to determine the effectiveness of the relationship amongst aforementioned elements to establish the significance of human capital existence in organisations operations.

\section{RESULTS AND DISCUSSIONS}

Table 1: Distribution of respondents regarding performance management system (Appraisal)

Disagree \% Agree \% Strongly Agree \%
Organisation operate a formal performance management system
High levels of performance are recognized and rewarded
The system is fair and legally defensible
The system supports developmental opportunities
Ratings are accurate and reflect actual performance
Performance problems are dealt with quickly and consistently
Performance Standards are consistent across the organization
Performance Appraisal meetings are meaningful and productive
Ratings are based on actual performance and not personal feelings
The appraisal process is simple and quick to do

\begin{tabular}{|c|c|c|c|c|}
\hline - & - & 120 & 40 & 180 \\
\hline 50 & 16.6 & 80 & 26.6 & 170 \\
\hline 40 & 13.3 & 100 & 33.5 & 160 \\
\hline 20 & 6.5 & 100 & 33.5 & 180 \\
\hline 50 & 16.5 & 100 & 33.5 & 150 \\
\hline 40 & 13.3 & 100 & 33.5 & 160 \\
\hline 40 & 13.3 & 100 & 33.5 & 160 \\
\hline 30 & 10 & 100 & 33.5 & 170 \\
\hline 60 & 20 & 100 & 33.5 & 140 \\
\hline 30 & 10 & 120 & 40 & 150 \\
\hline
\end{tabular}

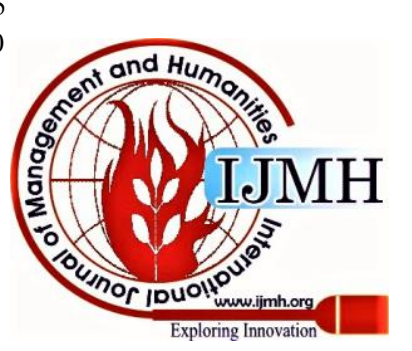


Table 1 above shows appraisal system conducted in various institutions. Information obtained from respondents clearly demonstrated the significance of performance appraisal in managing institutions human capital. Information revealed by respondents stated that, 120 (40\%) agreed whilst $180(60 \%)$ strongly agreed that the institutions operate a formal performance management system.

In continuance of other components, 50(16.6\%) noted that high level of performance are not recognised and rewarded whereas 80(26.6\%) agreed and 170(56.8) strongly agreed that employees are recognised and rewarded for high level of performance. Regarding respondents views about the fairness of the appraisal system, 40(13.3\%) disagreed that the system does not operate fairly whereas 100 (33.5\%) agreed and $160(53.2 \%)$ strongly agreed that the system is fair. Concerning opportunities for development within the organisations, 20(6.5\%) denied that the institutions do not provide opportunities for staff development. However, other respondents such as $100(33.5 \%)$ expressed that there are development opportunities for staff which is further strongly supported by $180(60 \%)$ respondent. The accuracy of organisations rating system was not supported by 50(16.5) respondent whilst $100(33.5)$ and $150(50 \%)$ mentioned that,ratings are accurate and reflect actual performance. Prompt response to performance challenges was disagreed by $40(13.3 \%)$ respondents, whilst $100(33.5)$ affirmed and $160(53.2 \%)$ strongly agreed that, authorities respond quickly and consistently in addressing performance problems. Consistency about standards across organisation was registered by $40(13.3 \%)$ respondents who noted that, standards are not consistent across the operations of organisations. However, 100(33.5\%) and 160(53.2\%) respondents demonstrated that, there is consistency in performance standards set across organisations. Productiveness of appraisal meeting was denied by 30(10\%) respondents whilst $100(333.5)$ and $170(56.5 \%)$ in their opinion, demonstrated that, appraisal meetings are productive. 60 (20\%) of the respondents noted that ratings are not based on actual performance but on personal feelings. However, 100(33.5\%) affirmed whilst 140 (46.5\%)established that, ratings are based on actual performance. Simplistic view about the appraisal process shows that,30(10\%) disagreed with the process being simple whereas $120(40 \%)$ and $150(50.0 \%)$ respondents demonstrated that, the process is simple and quick to conduct

Table 2: Distribution of respondents concerning training and employee development

\begin{tabular}{lcccccc}
\hline \multicolumn{1}{c}{ Indicators } & \multicolumn{4}{c}{ Rating } \\
& \multicolumn{1}{c}{$\begin{array}{c}\text { Disagree \% } \\
\text { Agree }\end{array}$} & $\begin{array}{c}\text { A } \\
\text { Strongly Agree }\end{array}$ \\
This organisation consider training as part of its development strategy & 30 & 10 & 100 & 33.3 & 170 & 56.7 \\
Induction training is a well-planned exercise in your organisation & 60 & 20 & 110 & 36.5 & 130 & 43.5 \\
Training helps to increase employee motivation level & 30 & 10 & 120 & 40 & 150 & 50.0 \\
Training improves employees knowledge, skills and competencies & 30 & 10 & 120 & 40 & 150 & 50.0 \\
Employee development leads to outstanding performance & 60 & 20 & 100 & 33.5 & 140 & 46.5 \\
Training increases employees productivity level & 50 & 16.5 & 100 & 33.5 & 150 & 50.0 \\
Training improves employer-employee relationship & 60 & 20 & 100 & 33.5 & 140 & 46.5 \\
Employees transfer learning on the job after attaining training & 30 & 10 & 130 & 43.5 & 140 & 46.5 \\
Training increases employees efficiency level & 30 & 10 & 130 & 43.5 & 140 & 46.5 \\
Training enhances professionalism and career advancement & - & - & 130 & 43.5 & 170 & 56.5 \\
\hline
\end{tabular}

Table 2 describe the relevance of staff capacity building as a significant component towards managing human capital. From the content shown above, it is vividly clear that staff capacity building serves as a contributing factor towards effective human capital management. Survey data shows the following details expressed by respondents with varying opinions and views. 30(10\%) of the respondents indicated that training is not part of their organisations development strategy. However, 100(33.3\%) and 170(56.7\%) strongly established that organisations consider training as a key development strategy. Regarding planning for induction training programmes conducted for new recruits, 60(20\%) respondents noted that induction training is not well planned. Nevertheless, 100(36.5\%) agreed whereas 130(43.5\%) strongly agreed that, induction training is properly planned before its implementation. The role of training towards employee motivation is shown by $30(10 \%)$ respondents who declared that training does not increase employee motivation level. In furtherance, 120(40\%) and 150(50\%)respondents respectively strongly confirmed that training increases employee motivation level. Competencies and skills acquisition is shown by $30(10 \%)$ respondents who disagreed that training does not improve employees' knowledge and skills. However, 120(40\%) and 150(50\%) confirmed that training improves employees knowledge, skills and competencies. Regarding staff development, $60(20 \%)$ respondents declared that staff development does not lead to exceptional performance. Alternatively, $100(33.5 \%)$ and 140(46.5\%) respondents strongly demonstrated that workforce development leads to outstanding performance.Increase in productivity level through training was objected by 50(16.5\%) respondents who expressed that training does not increase productivity level. Nevertheless, 100(33.5\%) affirmed whilst 150(50.0\%) strongly agreed that training increase productivity level of employees. Regarding effective relationship, 60(20\%) respondents expressed that training does not improve employer-employee relationship. However, 100(33.5\%) established with support by $140(46.5 \%)$ respondents that,training improves employer-employee relationship. Knowledge transfer after the conduct of training was challenged by $30(10 \%)$ of the respondents who disagreed that employees do not transfer concepts learnt to their daily duties.

Published By: 
On the contrary, 130(43.5\%) declared whilst 140(46.5\%) strongly agreed that employees transfer knowledge gained in training to their routinetasks.Regarding level of efficiency demonstrated by employees in organisations, 30(10\%) respondents shows that training alone does not increase employees' level of efficiency. On the other hand, $130(43.5 \%)$ and $140(46.5 \%)$ respectively expressed that employees efficiency is increased by effective training programme conducted in the different organisations. The enhancement of professionalism and career development was supported by $130(43.5 \%)$ and $170(56.5 \%)$ respondents who collective demonstrated their views that training facilitates professionalism and career growth.

Table 3: Distribution of respondents on high employee engagement and commitment

\begin{tabular}{|c|c|c|c|c|c|c|}
\hline \multirow[t]{2}{*}{ Indicators } & \multicolumn{6}{|c|}{ Rating } \\
\hline & Disagree \% & Agre & e $\%$ & Stron & gly Agree \% & \\
\hline The organisation provide opportunities for career advancement & 40 & 13.3 & 100 & 33.5 & 160 & 53.2 \\
\hline There is adequate company support for skills development & 60 & 20 & 100 & 33.5 & 140 & 46.5 \\
\hline The organisation provide all the tools needed for effective job per & formance 90 & 30 & 90 & 30 & 120 & 40.0 \\
\hline Engagement cultivates an environment of self-improvement & 60 & 20 & 130 & 43.5 & 110 & 36.5 \\
\hline Management demonstrates profound interest in staff well-being & 60 & 20 & 100 & 33.5 & 140 & 46.5 \\
\hline Engagement increases productivity & 30 & 10 & 120 & 40.0 & 150 & 50.0 \\
\hline Engagement enhances employee motivation & 30 & 10 & 100 & 33.5 & 170 & 56.5 \\
\hline Engagement addresses performance deficiencies & 60 & 20 & 120 & 40.0 & 120 & 40.0 \\
\hline Effective staff engagement leads to outstanding performance & 30 & 10 & 100 & 33.5 & 170 & 56.5 \\
\hline High employee engagement minimis & 60 & 20 & 100 & 33.5 & 140 & 46.5 \\
\hline Engagement strengthens employer and employee relationship & 60 & 20 & 110 & 36.5 & 130 & 43.5 \\
\hline
\end{tabular}

Table 3 outlines key elements that constituteeffective relationship through staff engagement. Therefore, it presents views and opinions of respondents which note how staff engagement serves as a significant human capital management component. In the survey conducted, career development was assessed by participants wherein 40(13.3\%) mentioned that their organisations do not provide career development opportunities for staffs. However, 100(33.5\%) agreed whilst 160 (53.2\%0 strongly agreed that career advancement opportunities are available for all classes of employees. Regarding employees' skills development, 60(20.5\%) indicated that, there is no organisational support for skills development. Conversely, $100(33.5 \%)$ and 140(46.5\%) strongly established that organisations provide adequate support for skills development. Respondents with $30 \%$ representation accentuated that organisations do not provide employees with the required tools to enhance exceptional performance. Nevertheless, another set of respondents with (30\%) indicated a contrary view towards views afore expressed which is supported by $120(40 \%)$ who strongly agreed that adequate tools are provided for effective and efficient execution of tasks. Self-improvement through engagementis shown by60(20\%) respondents who disagreed that engagement does not create an enabling environment for self-improvement. Furthermore, 130(43.5\%) agreed whereas $110(36.5 \%)$ strongly agreed that engagement facilitate selfimprovement.Concerning management's effort towards staff well-being, 60(20\%)respondents mentioned that, management does not show interest in staff well-being. However, 100(33.5\%) and 140(46.5) collectively declared and strongly agreed that management exhibit profound interest in employee well-being. Productivity increase through effective engagement is shown by $30(10 \%)$ respondents who disagreed that engagement does not increase productivity. Alternatively, 120(40.0\%) agreed whilst 150(50.0\%) strongly agreed that engagement increases employee productivity level. Employee motivation from $30(10 \%)$ participants' perspectives shows that motivation is not facilitated by engagement. Conversely, other sets of respondents with (33.5\%) and (56.5\%) strongly agreed that staff inspiration is enhanced by effective engagement.Issues about addressing performance fissures was declared by $60(20 \%)$ respondents who professed that engagement does not address performance gaps. On the other hand, two categories of respondents with $(40.0 \%)$ separately strongly agreed that engagement addresses performance deficiencies. Effective staff engagement which facilitates excellent performance was disagreed by $30(10 \%)$ respondents but further emphasised by greater percentages such as (33.5\%) and (56.5\%) respectively thateffective employee engagement accelerate employee outstanding performance. Minimising labour turnover was underscored by $60(20 \%)$ respondents that high employee engagement does not minimise staff turnover. Nevertheless, other sets of respondents such as 100(33.5\%) and 140(46.5\%) proclaimed that engagement minimises staff turnover. About employer-employee relationship, 60(20\%) of respondents shows that engagement does not reinforce employeremployee relationship. On the contrary, 110(36.5\%) and 130(43.5) respondents emphatically stated that staff engagement strengthens the relationship between employer and employees.

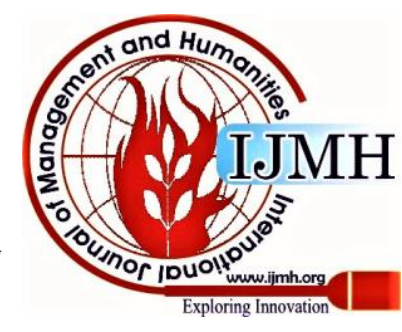




\section{Advantage}

Table 4: Distribution of respondents on rewards and compensation

\begin{tabular}{|c|c|c|c|c|c|c|}
\hline \multicolumn{2}{|l|}{ Indicators } & \multicolumn{5}{|c|}{ Rating } \\
\hline \multicolumn{7}{|l|}{ Disagree \% Agree \% Strongly Agree \% } \\
\hline This organisation has an efficient reward management system & 30 & 10 & 130 & 43.5 & 140 & 46.5 \\
\hline This Institution operate a traditional salary grade system & - & - & 130 & 43.5 & 170 & 56.5 \\
\hline The organisation offers rewards based on performance & 60 & 20 & 110 & 36.5 & 130 & 43.5 \\
\hline Employees are recognized for good work performance & 90 & 30 & 100 & 33.5 & 110 & 36.5 \\
\hline Employees are recognised for creative suggestions that improve performance & 90 & 30 & 90 & 30.0 & 120 & 40.0 \\
\hline Employees are recognised for sustained outstanding performance & 60 & 20 & 120 & 40.0 & 120 & 40.0 \\
\hline Formal recognition events increase employees motivational values & 60 & 20 & 140 & 46.5 & 100 & 33.5 \\
\hline The company offers comprehensive benefits package & 30 & 10 & 120 & 40.0 & 150 & 50.0 \\
\hline Financial motivation is the principal motivator & - & - & 100 & 33.5 & 200 & 66.5 \\
\hline The organisation award certificate as recognition for talents exhibition & 30 & 10 & 120 & 40.0 & 150 & 50.0 \\
\hline Compensation influences employee performance & 30 & 10 & 120 & 40.0 & 150 & 50.0 \\
\hline
\end{tabular}

Table 4 above analyses the contributions of rewards and compensation towards managing human capital in organisations. In response to questions regarding the subject matter, $30(10 \%)$ of the respondents indicated that their organisations do not have an efficient reward management system, however,130(43.5\%) and 140(6.5\%) demonstrated different views which noted, agreed and strongly agreedrespectively that, their organisations reward management system is efficient. Regarding grade system, $130(43.5 \%)$ and $170(56.5 \%)$ respondents correspondingly agreed that their organisations operate a traditional salary grade system. About rewards for performance, 60(20\%) respondents stated that, their organisation does not offer rewards based on performance; nevertheless, $110(36.5 \%)$ noted whilst $130(43.5 \%)$ strongly established that rewards are offered based on performance. In relation to recognition for remarkable performance 90(30\%) respondents noted that employees are not recognised for their good work, however, $100(33.5 \%)$ and $110(36.5 \%)$ separately mentioned that employees are recognised for outstanding performance exhibited.About creativity, it was indicated by $90(30 \%)$ respondents that employees are not recognised for creative suggestions that improves performance. Conversely, 90(30\%) and 120(40\%) respondents collectively demonstrated that, workers are appreciated for suggestions that improves performance. Recognition events held by organisations as inspirational values, shows that $60(20 \%)$ of the respondents disagreed that such events do not motivate employees. On the other hand, 140(46.5\%) confirmed whilst $100(33.5 \%)$ strongly supported that annual public/recognition occasions increases employee motivational values. $30(10 \%)$ of the respondents made it clear that their organisations do not offer comprehensive benefit package. However, other sets of respondents such as $120(40 \%)$ and $150(50 \%)$ proclaimed that their organisations offer comprehensive benefit package to all classes employees. As a result of the significance of financial resources towards effective human capital management, 100(33.5\%) agreed whilst 200(66.5\%) strongly agreed that financial motivation is the principal motivator towards employee performance. Staff recognition has always been efforts made by numerous institutions to facilitate retention through issuance of certificates and distribution of gifts etc. In relation to aforesaid, $30(10 \%)$ respondents stated that certificates are not awarded as recognition for talents display. However, greater percentages such as $120(40 \%)$ and $150(50 \%)$ respectively declared thatcertificates are issued to employees in recognition of talents exhibited in their jobs.

Correlations on Training, Engagement and Rewards

\begin{tabular}{|c|c|c|c|c|c|c|c|c|}
\hline & & 1 & 2 & 3 & 4 & 5 & 6 & 7 \\
\hline \multirow[t]{2}{*}{ OFPMS } & $\begin{array}{l}\text { Pearson Correlation } \\
\text { Sig. (2-tailed) }\end{array}$ & 1 & & & & & & \\
\hline & $\mathrm{N}$ & 300 & & & & & & \\
\hline \multirow{3}{*}{ TOCTDS } & Pearson Correlation & $.873^{* *}$ & 1 & & & & & \\
\hline & Sig. (2-tailed) & .000 & & & & & & \\
\hline & $\mathrm{N}$ & 300 & 300 & & & & & \\
\hline \multirow[t]{3}{*}{ TIEKSC } & Pearson Correlation & $.800^{* *}$ & $.930^{* *}$ & 1 & & & & \\
\hline & Sig. (2-tailed) & .000 & .000 & & & & & \\
\hline & $\mathrm{N}$ & 300 & 300 & 300 & & & & \\
\hline \multirow{3}{*}{ TOPTEJP } & Pearson Correlation & $.836^{* *}$ & $.815^{* *}$ & $.835^{* *}$ & 1 & & & \\
\hline & Sig. (2-tailed) & .000 & .000 & .000 & & & & \\
\hline & $\mathrm{N}$ & 300 & 300 & 300 & 300 & & & \\
\hline \multirow[t]{3}{*}{ ESEOP } & Pearson Correlation & $.873^{* *}$ & $1.000^{* *}$ & $.930^{* *}$ & $.815^{* *}$ & 1 & & \\
\hline & Sig. (2-tailed) & .000 & .000 & .000 & .000 & & & \\
\hline & $\mathrm{N}$ & 300 & 300 & 300 & 300 & 300 & & \\
\hline \multirow[t]{3}{*}{ ERSOP } & Pearson Correlation & $.764^{* *}$ & $.811^{* *}$ & $.846^{* *}$ & $.933^{* *}$ & $.811^{* *}$ & 1 & \\
\hline & Sig. (2-tailed) & .000 & .000 & .000 & .000 & .000 & & \\
\hline & $\mathrm{N}$ & 300 & 300 & 300 & 300 & 300 & 300 & \\
\hline \multirow[t]{3}{*}{ FREIEMV } & Pearson Correlation & $.720^{* *}$ & $.771^{* *}$ & $.798^{* *}$ & $.872^{* *}$ & $.771^{* *}$ & $.943^{* *}$ & 1 \\
\hline & Sig. (2-tailed) & .000 & .000 & .000 & .000 & .000 & .000 & \\
\hline & $\mathrm{N}$ & 300 & 300 & 300 & 300 & 300 & 300 & 300 \\
\hline
\end{tabular}

**. Correlation is significant at the 0.01 level (2-tailed). 
The table above shows correlation significance at 0.1 level 2-tailed. It clearly displayed the relationship of organisations components as significant towards managing institutions workforce. It however indicated that, an organisation that operate an efficient performance management system technically influence so many factors that enhances effective and efficient management of human capital. With a structured performance management system, one of its development strategies which will facilitate the enhancement of employees'knowledge, skills and competencies. Further issues emphasised are that, the provision of adequate tools needed for effective job performance and effective employee engagement, facilitate outstanding performance which leads to organisational development and sustainability.

Further indications highlighted that, employees that are recognised for sustained outstanding performance demonstrates commitment to their delegated duties. Such act of commitment, stem form effective employee engagement. which facilitate the efficient management of institutions human capital. Finally, itis established that, formal recognition events held annually serves as motivational values to employees which helps organisations to identify and retain talents for competitive benefits.

\section{CONCLUSION}

The study descriptively examine elements that constitutes the effective management of organisations human capital, which is a constituent components of intellectual capital. It examined different components that necessitate efficient workforce management which leads to organisational development and sustainability. Thorough review of pieces of literature established that,a structured performance management system, effective staff capacity building programmes, dynamic employee engagement and strategic management of financial and non-financial rewards facilitate the efficient management of organisations human capital. However the aforementioned is reinforced by survey data through respondents' views and opinions which categorically demonstrate that training empowers institutions workforce for outstanding performance whereas high employee engagement facilitate staff commitment. Furthermore, it was discovered that suitable allocations of financial and non-financial rewards serves as motivational values which stimulate employees to unleash their creative acumen for sustainable institutions growth. The methods used for collecting data enabled the discovery of aforementioned facts that can be used for administrative and academic purposes. Results of this study will aid organisations used as case studies and will also contribute towards academia, enhance knowledge for human capital specialists and general management practitioners. However, future endeavours could be expandedusing a larger sample size and sample frame or elements discussed could probably be examined differently towards the discovery of further facts about the subject matter.

\section{ACKNOWLEDGEMENTS}

1 wish to acknowledge contributions of management and staff of Sierra Leone Commercial Bank and Rokel support towards gathering primary data which enhanced the organisations will consider training and staff development as Commercial Bank (Sierra Leone Limited) for their immense

development and completion of this research. Furthermore, I appreciate colleagues who availed themselves for the distribution and retrieval of questionnaires which provided data for analysis, discussion and conclusion of the subject matter.

\section{REFERENCES}

1. Adler, P. S., \& Kwon, S. W. (2002). Social capital: Prospects for a new concept. Academy of Management Review, 27(1), 17-40.

2. Alavi, M., \& Leidner, D. E. (2001). Review: Knowledge management and knowledge management systems: Conceptual foundations and research issues. MIS Quarterly, 25(1), 107-136.

3. Anand, N., Gardner, H. K., \& Morris, T. (2007). Knowledge-based innovation: Emergence and embedding of new practice areas in management consulting firms. Academy of Management Journal, 50(2), 406-428

4. Andreeva, T., \& Kianto, A. (2012). Does knowledge management really matter? Linking knowledge management practices, competitiveness and economic performance. Journal of Knowledge Management, 16(4), 617-636.

5. Barai, P., \& Mohanty, P. (2014). Role of industry relatedness in performance of Indian acquirers-Long and short run effects. Asia Pacific Journal of Management, 31(4), 1045-1073.

6. Barney, J B (1991) Firm resources and sustained competitive advantage, Journal of Management Studies, 17 (1), pp. 99-120

7. Berger, A. N., Goulding, W., \& Rice, T. (2014). Do small businesses still prefer community banks? Journal of Banking \& Finance, 44, 264-278

8. Berger, A. N., \& Udell, G. F. (2002). Small business credit availability and relationship lending: The importance of bank organisational structure. The Economic Journal, 112(477), F32-F53.

9. Beugelsdijk, S. (2008). Strategic human resource practices and product innovation. Organization Studies, 29(6), 821-847.

10. Bitler, M. P., Robb, A. M., \& Wolken, J. D. (2001). Financial services used by small businesses: Evidence from the 1998 survey of small business finances. Federal Reserve Bulletin, 2001(April), 183-205.

11. Boot, A. W. A. (2000). Relationship banking: What do we know? Journal of Financial Intermediation, 9(1), 3-25.

12. Bontis, N. (1998) Intellectual capital: an exploratory study that develops measures and models, MCB University Press.

13. Bontis, N., Keow, W. C. C., \& Richardson, S. (2000). Intellectual capital and business performance in Malaysian industries. Journal of Intellectual Capital, 1(1), 85-100.

14. Bowen, D. E., \& Ostroff, C. (2004). Understanding HRM-firm performance linkages: The role of the 'strength' of the HRM system. Academy of Management Review, 29(2), 203-221.

15. Breaugh, J., \& Starke, M. (2000). Research on employee recruitment: So many remaining questions. Journal of Management, 26(3), 405434

16. Butler, A. W., \& Goktan, M. S. (2013). On the role of inexperienced venture capitalists in taking companies public. Journal of Corporate Finance, 22, 299-319.

17. Cabello-Medina, C., López-Cabrales, A., \& Valle-Cabrera, R. (2011) Leveraging the innovative performance of human capital through HRM and social capital in Spanish firms. International Journal of Human Resource Management, 22(4), 807-828.

18. Cabrita, M. R., \& Bontis, N. (2008). Intellectual capital and business performance in the Portuguese banking industry. International Journal of Technology Management, 43(1-3), 212-237.

19. Chang, W., Franke, G. R., \& Lee, N. (2016). Comparing reflective and formative measures: New insights from relevant situations. Journal of Business Research, 69(10), 3177-3185.

20. Critchfield, T., Davis, T., Davison, L., Gratton, H., Hanc, G., \& Samolyk, K. (2004). Community banks: Their recent past, current performance, and future prospects the future of banking in America. FDIC Banking Review, 16(3), 1-56.

21. Davis, D. F., Golicic, S. L., \& Marquardt, A. J. (2008). Branding a B2B service: Does a brand differentiate a logistics service provider? Industrial Marketing Management, 37(2), 218-227.

22. Dineen, B. R., \& Williamson, I. O. (2012). Screening-oriented recruitment messages: Antecedents and relationships with applicant pool quality. Human Resource Management, 51, 343-360

Published By: 
23. Edler, J., Georghiou, L., Blind, K., Uyarra E. (2012). Evaluating the Demand Side: New Challenges for Evaluation. Research Evaluation, 21, (1), pp. 33-47

24. Ghoshal, S. (2005). Bad management theories are destroying good management practices. The Academy of Management Learning and Education, 4(1), 75-91.

25. Giangreco, A., Carugati, A., Sebastiano, A., Tamimi, H. A., 2012: War outside, ceasefire inside: An analysis of the performance appraisal system of a public hospital in a zone of conflict. Eval Program Plann, 35, 1: 161-170. ISSN 0149-7189

26. Gubbi, S. R., Aulakh, P. S., \& Ray, S. (2015). International search behavior of business group affiliated firms: Scope of institutional changes and intragroup heterogeneity. Organization Science, 26(5), 1485-1501

27. Haggerty, C., Grigorian, K., Harter, R., \& Stewart, A. (2001). The 1998 survey of small business finance. Methodology Report Board of Governors of the Federal Reserve

28. Hitt, M. A., Keats, B. A, \& DeMarie, S. M. (1998). Navigating in the new competitive landscape: Building strategic flexibility and competitive advantage in the 21st century. Academy of Management Executive, 12, 22-42.

29. Jackson, S, E, Denisi, A, \& Hitt, M. (2003). Managing Knowledge for Sustained Competitive Advantage. Designing strategy for human resource management. San Francisco USA: John Wiley \& Sons, Inc.

30. Lebedev, S., Peng, M. W., Xie, E., \& Stevens, C. E. (2015). Mergers and acquisitions in and out of emerging economies. Journal of World Business, 50(4), 651-662

31. Lee, C. Y., Lee, J. H., \& Gaur, A. S. (2017). Are large business groups conducive to industry innovation? The moderating role of technological appropriability. Asia Pacific Journal of Management, 34(2), 313-337.

32. Manish Poplia, Radha M. Ladkania, Ajai S. Gaurb (2017), Business group affiliation and post-acquisition performance: An extended resource-based view, Journal of Business Research, Elsevier, p 1-10

33. Mayer, K. J., \& Argyres, N. S. (2004). Learning to contract: Evidence from the personal computer industry. Organization Science, 15(4), 394-410.

34. Nickerson, J. A., \& Silverman, B. S. (2003). Why firms want to organize efficiently and what keeps them from doing so. Administrative Science Quarterly, 48(3), 433.

35. Nonaka, I. and Takeuchi, H. (1995), The Knowledge- Creating Company, Oxford University Press, New York, NY

36. O'Brien, J. (2003). The capital structure implication of pursuing a strategy of innovation. Strategic Management Journal, 24(5), 415-431

37. Peteraf, M. A. (1993). The cornerstones of competitive advantage: A resource-based view. Strategic Management Journal, 14, 179-191.

38. Petersen, M. A., \& Rajan, R. G. (2002). Does distance still matter? The information revolution in small business lending. The Journal of Finance, 57(6), 2533-2570.

39. Romano, C. A., Tanewski, G. A., \& Smyrnios, K. X. (2001). Capital structure decision making: A model for family business. Journal of Business Venturing, 16(3), 285-310.

40. Saparito, P., Elam, A., \& Brush, C. (2013). Bank-firm relationships: Do perceptions vary by gender? Entrepreneurship: Theory and Practice, 37(4), 837-858.

41. Sasson, A. (2008). Exploring mediators: Effects of the composition of organizational affiliation on organization survival and mediator performance. Organization Science, 19(6), 891-906

42. Sasson, A., \& Fjeldstad, Ø. D. (2009). Information-mediated network effects: Network composition and customer benefit in the presence of information asymmetry. Strategic Organization, 7(4), 355-386.

43. Saxena, G. (2015). Imagined relational capital: An analytical tool in considering small tourism firms' sociality. Tourism Management, 49, $109 \mathrm{e} 118$

44. Sharabati, A. A. A., Naji Jawad, S. \& Bontis, N. (2010).Intellectual capital and business performance in the pharmaceutical sector of Jordan. Management decision, 48, 105-131

45. Smelly, R. L., \& Li, M. F. (2000). Environmental dynamism, capital structure and performance: A theoretical integration and empirical test. Strategic Management Journal, 21(1), 31-49

46. Stein, J. C. (2002). Inforamtion production and capital allocation: Decentralized versus hierarchical firms. Journal of Finance, 107(5), 1891-1921

47. Stewart, T.A. (1995), "Trying to grasp the intangible", Fortune, 2 October, pp. 157-61.

48. Stewart, T.A. (1997), Intellectual Capital: The New Wealth of Organizations, Doubleday/Currency, New York, NY.

49. Stewart, T.A. (2001), The wealth of knowledge: intellectual capital and the twenty-first century organization. Doubleday/Currency, New York
50. Sveiby, K.E. (1997), The New Organizational Wealth: Managing and Measuring Knowledge Based Assets, Berrett-Koehler, New York, NY.

51. Sydler, R., Haefliger, S. Pruksa, R. (2014). Measuring intellectual capital with financial figures: Can we predict firm profitability? European Management Journal, 32, 244-259

52. Tetlock, P. E. (2000). Cognitive biases and organizational correctives: Do both disease and cure depend on the politics of the beholder? Administrative Science Quarterly, 45(2), 293-326.

53. Uzzi, B., \& Gillespie, J. J. (2002). Knowledge spillover in corporate financing networks: Embeddedness and the firm's debt performance. Strategic Management Journal, 23(7), 595-618.

54. Uzzi, B., \& Lancaster, R. (2003). Relational embeddedness and learning: The case of bank loan managers and their clients Management Science, 49(4), 383-399.

55. Vincente-Lorente, J. D. (2001). Specificity and opacity as resourcebased determinants of capital structure: Evidence for Spanish manufacturing firms. Strategic Management Journal, 22(2), 157-177.

56. Walters M. Louise (2013). The Importance of Training and Development in the Workplace, Savannah, GA 31406

57. Winerip, M. (2013). 35 Indicted in test scandal at Atlanta schools New York Times, A1.

58. Wooldridge, J. M. (2003). Introductory econometrics. Mason, OH: South-Western

59. Yıldız, S., Baştürk, F., Boz, İ.T. (2014). The effect of leadership and innovativeness on business performance. Procedia-Social and Behavioral Sciences, 150, 785-793.

\section{AUTHORS PROFILE}

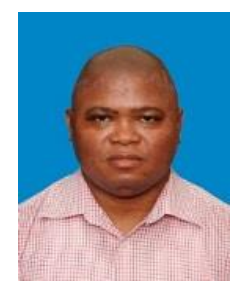

ABDUL AMID AZIZ JALLOH, is a certified Human Resources Management Practitioner and is also currently a $\mathrm{PhD}$ scholar in business administration with speciality in human resources management at the School of Economics and Business Administration - Chongqing University in China. He is a graduate of Universidad Empresarial de Costa Rica with a Master of Business Administration in Strategic Management. He also holds Master of Science in Corporate Management and Bachelor Science in Entrepreneurship and Human Capital Management. He has extensive knowledge in Human resource management practice and his research areas are Strategic Human Resource Management, Organisational Behaviour, Performance Management, Management theory and Practice, Business Communication, Employee Relations and Negotiations, Entrepreneurship, Total Quality Management and Corporate Governance and Leadership

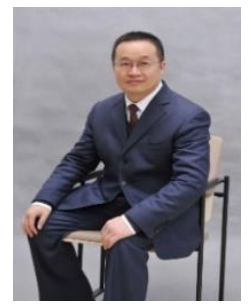

Professor Feng Ming, is a Professor of Management at Chongqing University in China. He holds a $\mathrm{PhD}$ in Industrial and Organizational Psychology from Zhejiang University, Master's degree in General Psychology and a Bachelor of Education from Southwest University in China. He is currently the Head of the Department of Management at the School of Economics and Business Administration - Chongqing University. He has published numerous articles and authored many books on Human Resource Management, Industrial Psychology, Organisational Behaviour and Knowledge Management. His research areas are: Human Resource Management, Organisational Behaviour and Applied Psychology.

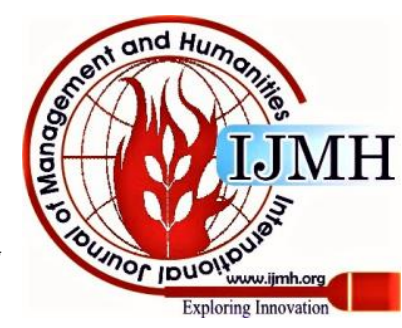

